\title{
An analysis of Service Quality on Mustahiq Satification using the Kano Model (Case Study on Baitul Mal)
}

\author{
Anwar and Khalsiah
}

University of Malikussaleh, Lhokseumawe, Indonesia

\begin{abstract}
Purpose - The purpose of this study is to find out the attributes that belong to the Kano category, which should be applied in the service quality of Baitul Mal Kota Lhokseumawe. In its service Baitul Mal must be prosecuted to prioritize satisfaction of mustahiq, so that the progress will be in the quality of service and able to improve the mustahiq economy and also give a positive impact on the survival of Baitul Mal.

Design/Methodology/Approach - This method is used in order to know the attributes that should be upgraded in accordance with the wishes of mustahiq. Finding the result shows that these methods allow us to know the priority attributes that must be improved its performance by the Baitul Mal. It is the Amil of Baitul Mal Kota Lhokseumawe act based on Islamic morality. Amil Baitul Mal Kota Lhokseumawe solve the mustahiq problem related to Zakat program on time. Baitul Mal Kota Lhokseumawe always serve mustahiq effectively. Amil Baitul Mal Kota Lhokseumawe has knowledge about Zakat and the Zakat given by Baitul Mal can improve the prosperity of mustahiq, and Amil Baitul Mal Kota Lhokseumawe does not distinguish between mustahiq one and others.
\end{abstract}

Research Limitations/Implication - Baitul Mal is a social institution, which is engaged in the charity of Zakat fund raising for the sake of socially patterned and sustainable economy.

Keywords Mustahiq satisfaction, service quality, Kano model

All papers within this proceedings volume have been peer reviewed by the scientific committee of the Malikussaleh International Conference on Multidisciplinary Studies (MICoMS 2017).

\section{Introduction}

Baitul Mal is a social institution in charity Zakat fund raising. The service in the Baitul Mal is a very important thing to be underscored. The creation of service quality will certainly create satisfaction with mustahiq. In fulfilling the mustahiq satisfaction required the quality of service as well as possible and high commitment from the Amil, because mustahiq is the main target in the distribution of Zakat and able to prosper the life of the mustahiq to be better. Therefore, it is necessary to conduct research on Baitul Mal regarding the quality of services provided. It is because the quality of service will have so many positive impacts for the survival of Baitul Mal. The purpose of this study is to determine the attributes that

(C) Anwar and Khalsiah. Published in the Emerald Reach Proceedings Series. Published by Emerald Publishing Limited. This article is published under the Creative Commons Attribution (CC BY 4.0) licence. Anyone may reproduce, distribute, translate and create derivative works of this article (for both commercial and non-commercial purposes), subject to full attribution to the original publication and authors. The full terms of this licence may be seen at http://creativecommons.org/licences/by/4.0/ legalcode
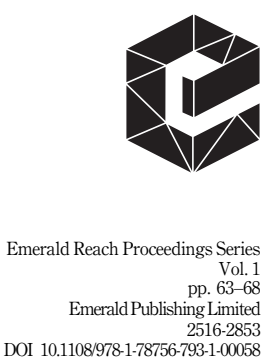
Proceedings of MICoMS 2017

\section{4}

belong to the Kano category, which should be applied in service quality of Baitul Mal Kota Lhokseumawe. There is Al-Qura'an's verse of Zakat in different terms. It has been mentioned by ma'rifah (Zakat treasure) as much as 30 times and it is eight times in surah makkiyyah and 22 times in madaniyyah. Then 28 verses related to the obligation to perform the prayer. This makes the position of Zakat high enough and important in the Islamic Shari'ah. Zakat can also cultivate mustahiq and muzakki relationships, enhancing ukhuwah islamiyyah and reducing poverty The Qur'an also states that Zakat is the main indicator of one's obedience to the teachings of Islam, which will gain the happiness of life, gain the grace, and help Allah Swt.

\subsection{Definition of service quality and kano model}

Kano model developed by Noriaki Kano (1984) which aims to categorize the attributes of products and services based on how well the product is able to satisfy the needs mustahiq. The service quality is how far the difference between the reality and expectations of the mustahiq for the service they receive. The quality of service can be identified by comparing the mustahiq perceptions of the services they actually receive.

\section{Method}

The method used in this research is taken with case study method through interview to mustahiq which become respondent by using questionnaire. Sampling is done by nonrandom sampling technique that is the procedure of selecting sample based on consideration certain characteristic which is suitable and needed to answer the research questions. The characteristics of sample taken in this research is fakir that is as much as 87 respondents. The sampling selection using Slovin formula where $90 \%$ confidence level and error term around 10\%. Kano model developed by Noriaki Kano (1984) which aims to categorize the attributes of products and services based on how well the product is able to satisfy the needs mustahiq.

In terms of language, Zakat has several meanings, namely al-barakatu (blessing), alnama (growth and development), al-tharatu (purity), and al-salahu (goodness). On the behalf of jurisprudence, Zakat is a number of property that is obligated by Allah to be handed over to the rightful. Zakat is part of the property with certain conditions required by Allah SWT to be shared to the rightful to receive it with certain conditions. Zakat is māliyah ijtimā'iyyah service that has an important, strategic, and decisive position from the point of doctrine and the development of the welfare of the people. Zakat is included in the pillars of Islam, so it is considered ma'lum minad-din bi al-darurah (known automatically) and is an absolute part of one's religion. Even in the Qur'an there are also verses that equate the level of prayer and the obligation of Zakat. There is al-Qura'an's verse of Zakat in different terms. It has been mentioned by ma'rifah (Zakat treasure) as much as 30 times and it is eight times of which are in the surah makkiyyah and 22 times in madaniyyah. Then 28 verses related to the obligation to perform the prayer. This makes the position of Zakat high enough and important in the Islamic Shari'ah. Zakat can also cultivate mustahiq and muzakki relationships, enhancing ukhuwah islamiyyah and reducing poverty. The Qur'an also states that Zakat is the main indicator of one's obedience to the teachings of Islam, which will gain the happiness of life, gain the grace, and help of Allah Swt. A person who fulfills the obligatory obligation is one who wishes to cleanse oneself and his soul from various bad qualities, such as selfishness, greed, and at the same time desire to always cleanse, purify, and develop his possessions.

The people who are entitled to receive Zakat consist of eight groups, namely Fakir, that is, people who do not have anything or cannot meet half of the needs. 
(1) Poor, that people can meet half the needs.

(2) Amil, the person appointed to take care of Zakat.

(3) Muallaf, the new convert to Islam while his faith is strong.

(4) Slave, the servant who has been promised his master that he may redeem himself with money or other property.

(5) Gharimin, the people who have debts, the people who bear the burden of debt to improve human relations, or to meet their personal needs both rich and poor.

Analysis of Service Quality On Mustahiq Satisfaction

(6) Fisabilillah, it is jihad and everything needed with jihad activities, such as recruitment of war troops, the establishment of factories, and the arms industry.

(7) Ibn Sabil, it is all those who run out of life stock on the way and cannot bring his needs from his village, although he is a treasure in his village.

\section{Findings and Discussion}

The research was conducted at Baitul Mal in Kota Lhokseumawe. From the results of this research, it is illustrated that the distribution of questionnaires with the number of respondents based on Slovin method formula where the $90 \%$ confidence level and error term is $10 \%$. The results of the calculation of the mustahiq satisfaction coefficient, the results obtained is If Better than (IBT) and If Worse Than (IWT), for each attribute. Then the graph of Kano's mustahiq satisfaction coefficient can be seen in Figure 1.

Based on the above mustahiq satisfaction coefficient diagram, the attributes of Baitul Mal service can be grouped in each dimension. The attributes are included in one dimensional are eight attributes, attributes are included in the category of attractive are three attributes, attributes included in the category are seven attributes, and attributes belonging to the category of indifferent are six attributes.

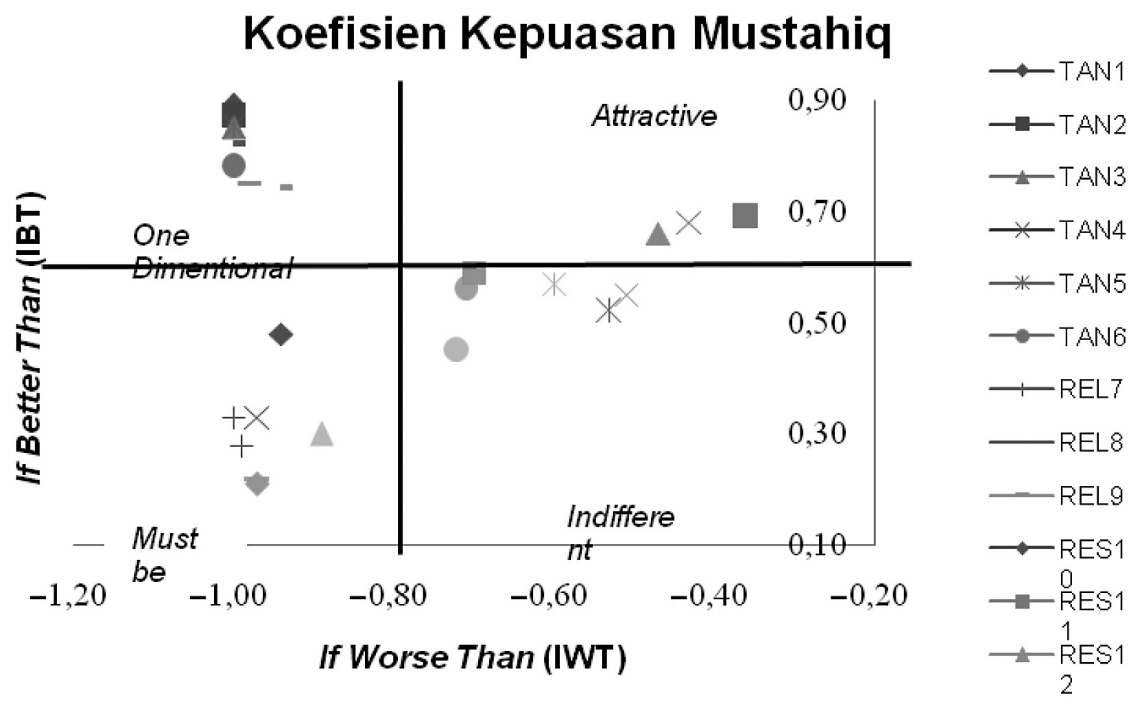

Figure 1.

The Diagram of Mustahiq Satisfaction 


\section{Proceedings of MICoMS 2017}

\begin{tabular}{lcl}
\hline Dimension & Attribute Codes & \\
\hline Tangible & TAN1 & Quitul Mal Kota Lhokseumawe has adequate building \\
& TAN2 & $\begin{array}{l}\text { Baitul Mal Kota Lhokseumawe has a comfortable building } \\
\text { Baitul Mal Kota Lhokseumawe has a clean building }\end{array}$ \\
& TAN3 & $\begin{array}{l}\text { Baitul Mal Kota Lhokseumawe has a neat building } \\
\text { Baitul Mal Kota Lhokseumawe has a service room in accordance with its } \\
\text { Tunction }\end{array}$ \\
& REL8 & $\begin{array}{l}\text { Amil Baitul Mal Kota Lhokseumawe is always in the office during } \\
\text { working hours }\end{array}$ \\
& REL9 & $\begin{array}{l}\text { Baitul Mal Kota Lhokseumawe has an easy registration procedure to } \\
\text { become mustahiq } \\
\text { Baitul Mal Kota Lhokseumawe has enough Amil, so there is always a } \\
\text { substitute if anyone is unable to attend }\end{array}$ \\
& ASS17 &
\end{tabular}

\section{6}

Table 1.

Service Attributes Which Included in One Dimensional
Based on the diagram of the coefficient of customer satisfaction above, the attributes of Baitul Mal service can be grouped in each dimension. The attributes that are included in one dimensional can be seen in Table 1 .

Baitul Mal service attributes included in the attractive that can be seen in Table 2.

The attributes of Baitul Mal service included in the must that can be seen in Table 3 .

Baitul Mal service attributes included in indifferent can be seen in Table 4.

\begin{tabular}{lcl}
\hline Dimension & Attribute Codes & \multicolumn{1}{c}{ Questions } \\
\hline Responsivness & RES11 & $\begin{array}{l}\text { Amil Baitul Mal Kota Lhokseumawe can answer the questions } \\
\text { posed by mustahiq }\end{array}$ \\
RES12 & $\begin{array}{l}\text { Amil Baitul Mal Kota Lhokse umawe is always willing to help the } \\
\text { mustahiq who are in trouble } \\
\text { Amil Baitul Mal Kota Lhokseumawe always listen to complaints of } \\
\text { mustahiq }\end{array}$ \\
RES13 &
\end{tabular}

Table 2.

Service Attributes Included in the Attractive

\begin{tabular}{lcl}
\hline Dimension & Attribute Codes & \multicolumn{1}{c}{ Questions } \\
\hline $\begin{array}{l}\text { Tangible } \\
\text { Reliability }\end{array}$ & TAN4 & $\begin{array}{l}\text { Amil Baitul Mal Kota Lhokseumawe shows Islamic morals } \\
\text { Amil Baitul Mal Kota Lhokseumawe solve the mustahiq problem } \\
\text { related to Zakat program on time }\end{array}$ \\
Responsivness & RES10 & $\begin{array}{l}\text { Baitul Mal Kota Lhokseumawe always serve mustahiq quickly } \\
\text { Amil Baitul Mal Kota Lhokseumawe has knowledge of Zakat }\end{array}$ \\
& ASS16 & $\begin{array}{l}\text { Zakat given Baitul Mal Lhokseumawe city has fulfilled the necessity of } \\
\text { mustahiq }\end{array}$ \\
Assurance & ASS18 & $\begin{array}{l}\text { Zakat given Baitul Mal Kota Lhokseumawe can improve the welfare of } \\
\text { mustahiq } \\
\text { Amil Baitul Mal Kota Lhokseumawe does not distinguish between } \\
\text { mustahiq one with another }\end{array}$ \\
Emphaty & EMP21 &
\end{tabular}

Table 3.

Service Attribute Included in the Must 


\begin{tabular}{|c|c|c|c|}
\hline Dimension & Attribute Codes & Questions & $\begin{array}{l}\text { Analysis of } \\
\text { Service }\end{array}$ \\
\hline \multirow[t]{2}{*}{ Assurance } & ASS14 & $\begin{array}{l}\text { Amil Baitul Mal Kota Lhokseumawe can explain the information to the } \\
\text { mustahiq in detail }\end{array}$ & Quality On \\
\hline & ASS15 & $\begin{array}{l}\text { Amil Baitul Mal Kota Lhokseumawe can explain the information to the } \\
\text { mustahiq clearly }\end{array}$ & Satisfactio \\
\hline \multirow[t]{4}{*}{ Emphaty } & EMP20 & $\begin{array}{l}\text { Amil Baitul Mal Kota Lhokseumawe is always willing to provide latest } \\
\text { information to mustahiq }\end{array}$ & \\
\hline & EMP22 & $\begin{array}{l}\text { Amil Baitul Mal Kota Lhokseumawe always give full attention to every } \\
\text { mustahiq }\end{array}$ & \\
\hline & EMP23 & $\begin{array}{l}\text { Amil Baitul Mal Kota Lhokseumawe always understands what the } \\
\text { mustahiq complained about }\end{array}$ & $\begin{array}{r}\text { Tabl } \\
\text { Service Attrib }\end{array}$ \\
\hline & EMP24 & $\begin{array}{l}\text { Amil Baitul Mal Kota Lhokseumawe always understands what the } \\
\text { mustahiq wants }\end{array}$ & $\begin{array}{r}\text { Included } \\
\text { Indiffere }\end{array}$ \\
\hline
\end{tabular}

\section{Conclusion}

Based on the results, it can be concluded that the service attributes in the category of must be attribute considered as a must, mustahiq will not be satisfied if the attributes in this category are not accomplished, among others and Amil Baitul Mal Kota Lhokseumawe show Islamic morality, Amil Baitul Mal Kota Lhokseumawe solve the mustahiq problem related to Zakat program on time. Baitul Mal Kota Lhokseumawe should also serve mustahiq quickly, and Amil Baitul Mal Kota Lhokseumawe have knowledge about Zakat. Futhermore, Zakat given Baitul Mal Kota Lhokseumawe has fulfilled the necessity of mustahiq and able to improve the welfare of mustahiq, and Amil Baitul Mal Kota Lhokseumawe does not differentiate between mustahiq one with the others. Service attributes can be divided into several as follow: Must-be or basic needs (M) Mustahiq considers that the attributes present in this category are a necessity in the product. Mustahiq will not be satisfied if the attributes that exist in this category are not met. One dimensional or performance needs (O)Mustahiq satisfaction will increase if the attributes that exist in this category are given, but mustahiq also will not be satisfied if the attributes that exist in this category does not exist.

Mustahiq does not care about the attributes offered so that the presence or absence of these attributes will not affect the increase or decrease in the level of satisfaction of the mustahiq. Sometimes mustahiq is satisfied or absent with the presence of attributes in this category, so it is not clear whether the attributes in this category are expected or not expected by mustahiq, or in other words, a denial in the mustahiq answer to the given question. Mustahiq not satisfied if there are attributes in this category, but mustahiq will be satisfied if the attribute in this category does not exist. It is expected that the Amil Baitul Mal can improve its service attribute performance based on expectations from mustahiq. This research can be continued by analyzing the factors causing the low performance of some important service attributes, so that the improvement of Baitul Mal service quality can be put forward as a public sector.

\section{References}

Hanoum, S. (2009). Prioritizing Healthcare Service Attributes. Comparing Importance Performance Analysis and Kano model". Tugas Akhir. Program Teknik Industri, Institut Teknologi Surabaya (ITS).

Majma Lughah al-'Arabiyyah. (1972). Al-Mu’jām al-Wasìt. Dār al-Ma'ārif, Misr, p. 396. 
Proceedings of Mulyani. (2008). "Analisis Sistem Laporan dana ZIS Pada Baitul MaalMuamalat (BMM) Jogjakarta". MICoMS 2017 Jurnal Dinamika Ekonomi and Bisnis, Vol. 5, No. 2.

1-Qurān, Bayrut: Dār al-Kutūb al-Ilmiyyah, h. 156. Qaraḍāwī (1985). op. cit,, h. 44. Hasbi As-Siddiqy (2006). op. cit., h. $4-5$.

Qarad̦āwī, Y. (1993). Al-'Tbādah Fī al-Istäm. Bayrut: Muassasah al-Risālah, h. 235.

QS. Al-Tawbah: 73 dan QS. al-Hajj: 40-41.

68

QS. Al-Tawbah: 103 dan QS. al-Rūm: 39. Baca Al-Qurțubî (1993). al Jāmi' li Aḥkām a.

Sabiq, S. (1968). op.cit., h. 5. Lihat juga Yūsuf Qaraḍāwī (1985). op. cit., h. 44. Hasbi As-Siddiqy (2006). op. cit., h. 4-5.

Tjiptono, F. (2001). Strategi Pemasaran. Andi Offset, Yogyakarta.

Yafie, A. (1994). Menggagas Fiqh Sosial. Bandung: Mizan, h. 231.

Walden. (1993). "Kano's Methods for Understanding Customer Defined Quality". Center for Quality of Management Journal, Vol. 2.

\section{Corresponding author}

Anwar can be contacted at anwar_muhammadali@yahoo.co.id 